\title{
The Research into the Innovative Strategies of Badminton Teaching in Colleges and Universities
}

\author{
Jun Tao \\ Physical Education Department \\ Wuhan Technology and Business University \\ Wuhan, P.R.China
}

\begin{abstract}
As one of the important sports for national fitness program, the badminton sports can strengthen people's body and lessen the life pressure because it is recreational, interesting and easy to play with. The badminton teaching in colleges and universities cannot only improve college students' skills in playing badminton, but it can also increase the students' awareness of loving sports. However, there are a series of problems with the badminton teaching in colleges and universities. Therefore, how to teach the badminton creatively in colleges and universities has become an important question for educators to think about. This article, on the basis of explanation on the importance of badminton sports, is trying to reveal some problems with the badminton teaching in colleges and universities and propose some corresponding solutions to enlighten the badminton teaching in colleges and universities.
\end{abstract}

Keywords-badminton teaching; importance; innovative strategies

\section{INTRODUCTION}

Modern teaching theory has pointed out that the essential objective and main task of educational reform is to optimize the teaching methods. With the in-depth reform of PE teaching in colleges and universities, it has become an important content in the field of PE reform to explore the allnew PE teaching methods and boost the teaching quality. Badminton, as a traditional athletic sport game, is an popular fitness sport game. In recent years, with the increasing popularity of PE elective courses, like the other sports, the badminton has appealed to college students greatly. The badminton is a sport involving a lot of changeable skills and rules. It is a little difficult for college students to master the basic skills of badminton sports in the limited time of PE classes. So, it is necessary to study and explore the new teaching methods of badminton.

\section{THE IMPORTANCE OF DEVELOPING THE BADMINTON SPORTS IN COLLEGES AND UNIVERSITIES}

\section{A. It Is of Great Help to Improve the Physical Fitness of College Students}

It has been revealed by sports physiology that the heart rate of the people who usually play badminton can reach 150 to 170 times per minute; even for the people who play badminton occasionally, their heart rate can also reach 100 to 130 times per minute. It is obvious that the badminton exercise is of sport physiological value. Doing the badminton sports in a long term can strengthen the heart and increase lung capacity. Besides, playing badminton for a long time can boost the strength of college students. It is not difficultly discovered that those who are powerful in hitting the feather ball, quick in moving their steps and waving the racket, flexible in playing badminton have very good qualities of strength. Through the badminton sport, college students can increase their strength and enhance their body power.

\section{B. It is of Great Help to Boost College Students Ideological Level}

The technology of badminton is rich and colorful, which makes it highly appreciable. In the process of appreciating badminton competition, college students can always produce a kind of empathy, and achieve spiritual satisfaction and sublimation. The feelings, such as depression and endurance after the failure, cheer and happiness after the victory, and especially the excitement when the national anthem is being played and the national flag is being flown, affect college students' mind and give them a strong spiritual incentive.

\section{It Is Helpful to Improve the Psychological Quality of College Students}

College students often participate in badminton sport, which can improve their psychological quality. In playing badminton, all kinds of emergencies often occur, and college students must be calm in the face of danger, in order to cope with all kinds of adversity. And the formation of this psychological quality can help college students with a good and stable mentality, a healthy and correct outlook on life to face the losses and gains.

\section{PROBLEMS IN BADMINTON TEACHING IN COLLEGES AND UNIVERSITIES}

At present, due to a series of subjective and objective factors, the current situation of badminton teaching in colleges and universities is not satisfactory, mainly reflected in the following points 


\section{A. Ignoring Individual Differences}

College sports courses are organized according to students' hobbies and interests. In each class, there are differences in students' physical quality and ability level. There are both students with good physical quality and good sports ability, as well as students with weak health, disease and poor balance ability. Due to the limitation of class, the physical education teachers, in the badminton teaching, arrange the same teaching content, set up the same teaching goal and organize the same exercise intensity. This way of teaching apparently ignores the students' individual differences, and problems will arise with the passage of time. For example, if students with poor sense of balance are asked to swing directly at the ball, they can't keep up with the teaching progress and lose interest in badminton. Nowadays, the teaching methods of "one size fits all" cannot meet the needs of badminton teaching. The badminton teacher must organize the teaching according to the actual situation of the students and aim at the target.

\section{B. Single Teaching Mode}

Related survey shows that only about $25 \%$ of colleges and universities use the modern education technology in the badminton teaching, and as many as $75 \%$ of colleges and universities still continue to use the traditional teaching mode that teachers explain and students imitate. Badminton skills have a lot of changes, so the teachers' explanation and demonstration are important, but the teacher's demonstration cannot cover all the aspects of badminton teaching, which may cause the students to think that as long as they learn teachers' technical action, they learn how to play badminton. This perception is clearly one-sided. In addition, the demonstration moves of the teachers are flashing and cannot be preserved for a long time. Under such circumstances, students cannot fully appreciate the essence of badminton technical movements. If we rely too much on the traditional teaching model, it will inevitably lead to the badminton teaching process becoming an "assembly line", which is difficult to achieve the teaching objectives.

\section{Poor Teaching Faculty}

In our country, badminton started late. The number of people who have studied badminton professionally is relatively small, and the number of teachers who have taught the badminton professionally is even smaller. Chinese colleges and universities have a hard and fast rule for teachers engaged in teaching, that is, teachers should have a master's degree or above. Due to the limited number of postgraduates majoring in badminton, few of them can be engaged in teaching, which leads to the weak strength of badminton teaching faculty in Chinese universities. For the moment, many teachers of badminton in the colleges and universities are other part-time professional sports teachers, who don't have the professional knowledge of badminton and solid badminton technology, so the teaching effect is difficult to significantly enhance.

\section{INNOVATING THE STRATEGY OF BADMINTON TEACHING IN COLLEGES AND UNIVERSITIES}

In conclusion, only by improving the current situation of badminton teaching in colleges and universities can we ensure the healthy development of the teaching process and realize the intrinsic value of badminton.

\section{A. Attaching Importance to Individual Differences of Students and Implementing Hierarchical Teaching}

It is an important prerequisite of innovating badminton teaching in colleges and universities to stimulate students' learning enthusiasm and initiative. Without the participation of students, badminton teaching has no value at all. In view of college students' different physical quality, receptivity, and sports foundation, the teachers must abandon the traditional teaching method of "one size fits all", otherwise it will cause the awkward phenomenon that students cannot get enough knowledge. Therefore, PE teachers should actively adopt hierarchical teaching method in badminton teaching. At the beginning of the semester, PE teachers should let students accept endurance, speed, sensitivity and other related physical quality test and special skills test, such as receiving and picking feather balls and according to the comprehensive test results, students can be divided into good, medium and poor levels. Different teaching objectives and contents should be formulated for students at all levels. Then, according to students' learning performance, students at all levels should be timely adjusted to stimulate their initiative and promote the improvement of the overall level.

\section{B. With the Help of Multimedia Technology, Urging Students to Grasp the Technical Action Firmly}

Technical teaching is one of the important contents of badminton teaching in colleges and universities. The basic technology of badminton is various and in limited teaching time, the teachers cannot teach students all skills. They only will choose to teach the key technology, and let the students learn to use the skills. Based on this point, teachers can select representative technical actions to teach students like how to grip, serve, bat the ball and footwork, for example, forehand and backhand grip, forehand shot, forehand shot, forehand shot, backcourt walk, etc. Then the relevant technology of the best international badminton players can be made into videos, which can be repeatedly watched by the students. Thus, students can listen to the teachers' detailed explanation, and firmly grasp techniques with the aid of multimedia technology.

\section{Carrying out the Integrated Teaching Inside and Outside the Class to Foster the Students' Physical Training Consciousness}

Nowadays, more and more teachers have recognized the organic combination of inside and outside classroom. After all, the time of classroom teaching is limited. Only with the help of extracurricular sports activities can we further consolidate and digest the knowledge and skills we have mastered. Badminton is exquisite, which requires the high skills, the endurance, speed, physical quality. If students do not consciously practice for a long time, it is difficult for 
them to firmly grasp the badminton technology. Therefore, the university badminton teaching urgently needs to implement the integration model combining the indoor and outdoor classes. Teachers should not only pay attention to classroom theory and basic technology teaching, but also pay attention to students' extracurricular practice, and arrange fixed places and equipment for students. Extracurricular exercises cannot stick to one pattern, which are designed to increase students' interest in badminton, cultivate their good habit of exercise for a long time, and encourage students to independently form a badminton club or establish interest groups on the basis of teachers' guide. Different groups and clubs can often organize matches to make progress together.

\section{Strengthening the Teaching Staff}

At present, there is still room for further improvement in badminton teaching faculty. Colleges and universities have to arrange some education training activities for badminton teachers and help badminton teachers improve innovation ability, technical ability, social ability, understanding ability, teaching ability and confidence, so as to play a role of good models for students. At the same time, colleges and universities can also arrange badminton teachers' competition activities, so that teachers can compete with each other and make progress together.

\section{CONCLUSION}

Badminton plays a vital role in improving college students' physical quality, psychological quality and ideological state. However, due to the restrictions of various reasons, there are many problems in badminton teaching in colleges, such as ignoring the individual differences of students, backward teaching mode and weak teaching faculty. Teachers must take effective measures to solve these measures, so that college students are still willing to play badminton after they leave the campus and lay a solid foundation for their lifelong development.

\section{REFERENCES}

[1] Deng Hui. The Thoughts on the Development and Problems of Current Badminton Sport in Colleges and Universities[J]. Science Education Forum. 2016(11).

[2] Zhou Wei. The Investigation and Analysis of Badminton Sport of College Students[J]. Sports Science and Technology Literature Bulletin. 2017(07).

[3] Weng Lin. The Development Situation and Strategies of Badminton Sport in Colleges and Universities [J]. Journal of Guangxi University of Nationalities, 2015(8). 